\title{
OCENA KORZYŚCI Z ROZWOJU ROLNICTWA EKOLOGICZNEGO REGIONU ZACHODNIOPOMORSKIEGO
}

\section{EVALUATION OF BENEFITS FROM DEVELOPMENT OF ORGANIC FARMING FOR WEST POMERANIAN REGION}

Zakład Rachunkowości, Politechnika Koszalińska

ul. Eugeniusza Kwiatkowskiego 6E, 75-343 Koszalin

\begin{abstract}
Summary. The aim of the study is to characterize how development of organic farming in West Pomeranian region affects on local economy, society and environment. Based on the data from the surveys, an attempt was made to assess whether organic farms are considered desirable by the local population and authorities in a given region, and how their existence contributes to the development of these areas. These farms are perceived as entities that, by producing, do not damage the natural environment, on the contrary they protect, preserve and properly shape the landscape of the village. They should definitely strengthen their local position, because the nearest environment in which they operate does not actually know them. The contribution of organic farms in the village of West Pomeranian local development is far too low in relation to their capabilities.
\end{abstract}

Słowa kluczowe: ekologiczne gospodarstwa rolne, korzyści, rozwój lokalny. Key words: organic farms, benefits, local development.

\section{WSTĘP}

W 2012 r. podczas Konferencji Narodów Zjednoczonych w sprawie Zrównoważonego Rozwoju Rio+ przyjęto komunikat końcowy „Bezpieczeństwo żywnościowe dzięki zrównoważonemu wzrostowi - gospodarka rolna oparta na ograniczonych zasobach". Wnioski płynące ze spotkania można streścić słowami:

- rolnictwo to kluczowy sektor dla budowy „zielonej gospodarki”;

- wzmocnienie rolnictwa i rozwój obszarów wiejskich przyczyni się do spowolnienia procesów urbanizacji, poprawi bezpieczeństwo żywnościowe, zwiększy zatrudnienie i poziom życia ludzi;

- rosnące zapotrzebowanie na żywność i surowce rolnicze oznaczają, że należy nasilić proces ochrony różnorodności biologicznej oraz wydajniejszego, bardziej zrównoważonego, wykorzystania gruntów rolnych oraz ziemi;

- rolnictwo ma wpływ na gospodarkę, społeczeństwo i środowisko na naszej planecie.

Uznano, że rolnictwo jest ważnym sektorem każdej gospodarki, każdego społeczeństwa i że ma nieoceniony wpływ na tworzenie warunków do życia na Ziemi. I chociaż dane publikowane w rocznikach statystycznych świadczą o tym, że udział rolnictwa (w stosunku do dwóch pozostałych sektorów gospodarki) w tworzeniu PKB systematycznie spada, to 
żaden kraj nie odważył się na zlikwidowanie tej formy działalności. Zmieniają się natomiast podejścia do sposobu i metod produkcji, dystrybucji, wykorzystania efektów produkcji rolniczej. Na przykład w Polsce od około 15 lat obserwuje się dość znaczny rozwój rolnictwa ekologicznego - rolnictwa, które zobowiązało się zasady, tj. zdrowotność, ekologię, sprawiedliwość i troskliwość, traktować jako całość, jako zespół norm etycznych inspirujących do działania. Powstało wiele opracowań naukowych potwierdzających dynamiczny rozwój tej formy działalności człowieka. Między innymi o historii i perspektywach rozwoju rolnictwa ekologicznego w Polsce pisały Domagalska i Buczkowska (2015). Kondratowicz-Pozorska (2013) skupiła się na ekonomiczno-organizacyjnych determinantach konkurencyjności ekologicznych gospodarstw rolnych w Polsce. Komorowska (2015) wskazała na rosnące znaczenie RE w gospodarce Polski, a Szarek i Nowogródzka (2015) wskazali, że rozwój gospodarstw ekologicznych nie w każdym regionie kraju jest podobny i ma takie samo nasilenie. Powstaje jednak pytanie, czy mieszkańcy terenów, na których prowadzone są ekologiczne gospodarstwa rolne (egr), są z tego faktu zadowoleni. Rozwój rolnictwa ekologicznego wiąże się przecież z rygorystycznymi wymogami dotyczącymi jakości i czystości gleby, powietrza i wód. Zapewnienie odpowiednich warunków dla egr może być jednocześnie barierą dla rozwoju innych form działalności na terenach wiejskich.

Celem publikacji jest wskazanie, jak rozwój rolnictwa ekologicznego w regionie wpływa na lokalną gospodarkę, społeczeństwo i środowisko. Próbowano ocenić, czy gospodarstwa ekologiczne są uważane przez okoliczną ludność i władze danego regionu za pożądane oraz w jaki sposób ich istnienie przyczynia się do rozwoju tych terenów.

\section{MATERIA I METODY}

Na potrzeby artykułu konieczne było przeprowadzenie studiów literaturowych z zakresu uwarunkowań rozwoju rolnictwa ekologicznego w Polsce. Przeanalizowano także wiele opracowań specjalistycznych instytucji, jak: IJHAR,IFOAM, IRWiR PAN i innych z ostatnich 15 lat. Jednocześnie, chcąc zrealizować cel pracy, przeprowadzono badania ankietowe. Uzyskane tą drogą wyniki miały przyczynić się do rozwiązania następujących kwestii:

- jak postrzegane jest funkcjonowanie ekologicznych gospodarstw rolnych (egr) przez mieszkańców wsi, w których gospodarstwa funkcjonują;

- jak oceniają funkcjonowanie egr władze regionu;

- jak postrzegają działalność egr właściciele przedsiębiorstw zlokalizowanych w sąsiedztwie.

Badania przeprowadzono w roku 2017 na terenie województwa zachodniopomorskiego.

Podmioty objęte badaniem to przedstawiciele władz gminy, gospodarstw domowych oraz właściciele podmiotów gospodarczych działających w bliższym lub dalszym sąsiedztwie egr. Realizując pierwszy etap prac, autorka niniejszego opracowania sprawdziła, w których gminach egr jest najwięcej. Ostatecznie wyznaczono do przeprowadzenia badania 20 gmin, tj. Barlinek, Biały Bór, Borne Sulimowo, Chociwel, Dobrą, Dolice, Goleniów, Koszalin, Malechowo, Manowo, Połczyn-Zdrój, Przelewice, Radowo Małe, Sławno, Stepnicę, Szczecinek, Świdwin, Trzcińsko-Zdrój, Widuchową i Wierzbno. Następnie ankiety wysłano do 20 wójtów zarządzających tymi gminami. W kolejnym etapie prac dokonano wizji lokalnej, aby określić liczbę gospodarstw domowych oraz liczbę podmiotów gospodarczych w bliższym lub 
dalszym sąsiedztwie egr. W 20 gminach ankiety skierowano do 5269 okolicznych gospodarstw domowych, z tego poprawnie wypełnionych zwrócono 1271, czyli $24 \%$. Zakwalifikowano do badania także 145 przedsiębiorców, którzy mają zarejestrowaną działalność gospodarczą, a ich firmy sąsiadują z egr. W badaniu uwzględniono te arkusze, które zawierały wszystkie odpowiedzi; było to ponad 109 ankiet, tzn. 75\%.

Każda grupa ankietowanych, tj. gospodarstwa domowe, przedsiębiorcy i wójtowie, otrzymała osobny kwestionariusz. Pytania były tak sformułowane, by zainteresowany był w stanie na nie odpowiedzieć. Każdy kwestionariusz zawierał 15 pytań, wśród których były pytania otwarte i zamknięte. Dodatkowo, aby określić siłę wpływu egr na rozwój regionu, wprowadzono skale ocen do niektórych pytań zawartych w kwestionariuszu, przy czym 1 oznacza ocenę bardzo złą, a 6 - ocenę wyróżniającą.

Na podstawie prac Sobieckiego (2007) i Adamowicza (2005), którzy określili 11 typowych zadań rolnika z egr, stworzono katalog 15 pytań. Przy tym 11 pierwszych pytań jest odzwierciedleniem owych zadań, które zostały jednakowo sformułowane dla każdej z trzech grup badawczych. Zadaniem respondenta było udzielić odpowiedzi „tak/nie” lub „nie wiem”, a w przypadku odpowiedzi „tak” wystawić ocenę (od 1 do 6) dla zadań realizowanych przez egr. Treść 11 pytań dotyczyła zagadnień:

1) czy egr w Pani/Pana otoczeniu wytwarza produkty żywnościowe, zdrowe, odpowiadające zapotrzebowaniom i preferencjom konsumentów, warunkom przetwarzania i dystrybucji w sposób nieszkodzący środowisku;

2) czy egr przygotowuje produkty do sprzedaży poprzez tradycyjne, ale też nowe, skrócone, zmodyfikowane kanały rynkowe bezpośrednio do sieci handlu detalicznego lub konsumentów;

3) czy egr, gospodarując w przestrzeni, poprawnie wykorzystuje zasoby przyrodnicze w Państwa otoczeniu na potrzeby gospodarcze i społeczne;

4) czy egr przeciwdziała depopulacji i dezertyfikacji (pustynnieniu, pustoszeniu);

5) czy egr konserwuje oraz kształtuje krajobraz i udostępnia lokalne zasoby przyrody społeczności lokalnej i przybyszom z zewnątrz;

6) czy właściciele i pracownicy egr uczestniczą w procesach rozwoju wsi poprzez kreowanie miejsc pracy w obrębie gospodarstwa rolnego i poza nim;

7) czy egr przyczynia się do tworzenia podstaw rozwoju pozarolniczych funkcji obszarów wiejskich, w tym budownictwa mieszkaniowego, instytucji edukacyjnych, przedsiębiorstw produkcyjnych i usługowych;

8) czy egr przyczynia się lub tworzy przestrzeń rekreacyjną na obszarach wiejskich poprzez przystosowanie terenu i rozbudowę infrastruktury oraz bazy noclegowej i gastronomicznej dla turystyki;

9) czy egr włącza się w proces zagospodarowania odpadów i recyklingu, zgodnie z wymogami środowiska i zasadami życia społecznego;

10) czy egr przyczynia się do zapobiegania klęskom i katastrofom żywiołowym oraz ogranicza ryzyko i skutki ich występowania poprzez tworzenie systemu ochrony przeciwpożarowej, przeciwpowodziowej i działań kontrolujących erozje;

11) czy egr ma wkład w zachowanie dziedzictwa kulturowego i historycznego Państwa wsi.

Kolejne cztery pytania, w zależności od grupy, do której je kierowano, były pytaniami szczegółowymi (częściowo otwartymi); przedstawiono je w tab. 1. 
Tabela 1. Charakterystyka pytań 12-15 skierowanych do trzech wybranych grup badawczych

\begin{tabular}{|c|c|c|c|}
\hline \multirow{2}{*}{$\begin{array}{l}\text { Numer } \\
\text { pytania }\end{array}$} & \multicolumn{3}{|c|}{ Grupy badawcze } \\
\hline & mieszkańcy wsi & włodarze & przedsiębiorcy \\
\hline 12 & $\begin{array}{l}\text { Czy ktoś z Państwa rodziny pra- } \\
\text { cuje w egr? Jeżeli tak, to ile } \\
\text { osób i jak długo? }\end{array}$ & $\begin{array}{l}\text { Jak wiele osób pracuje } \\
\text { w egr na terenie Państwa } \\
\text { gminy? }\end{array}$ & $\begin{array}{l}\text { Czy Państwa firma współpracuje } \\
\text { z egr na terenie w Państwa } \\
\text { gminy? }\end{array}$ \\
\hline 13 & \multicolumn{3}{|c|}{ Czy byli Państwo na terenie któregokolwiek egr w Państwa okolicy? Jeżeli tak, to w jakim celu? } \\
\hline 14 & $\begin{array}{l}\text { Czy przeszkadza Państwu } \\
\text { sąsiedztwo egr? Jeżeli tak, to } \\
\text { dlaczego? }\end{array}$ & $\begin{array}{l}\text { Czy występują jakieś trud- } \\
\text { ności w związku z tym, że } \\
\text { na terenie gminy działają } \\
\text { egr? }\end{array}$ & $\begin{array}{l}\text { Czy przeszkadza Państwu są- } \\
\text { siedztwo egr? Jeżeli tak, to } \\
\text { dlaczego? }\end{array}$ \\
\hline 15 & \multicolumn{3}{|c|}{$\begin{array}{l}\text { Czy słyszeli Państwo o inicjatywach społeczno-kulturalnych organizowanych lub inicjowanych przez } \\
\text { egr? Jeżeli tak, to o jakich? }\end{array}$} \\
\hline
\end{tabular}

\section{ROZWÓJ ROLNICTWA EKOLOGICZNEGO W WOJEWÓDZTWIE ZACHODNIOPOMORSKIM}

Obecnie niemal we wszystkich wysokorozwiniętych krajach rolnictwo konwencjonalne spotyka się z coraz większą krytyką. Powodem jest pogarszająca się jakość żywności produkowanej $w$ intensywnych systemach produkcji oraz destrukcyjny wpływ takiej produkcji na środowisko. Uprzywilejowane staje się natomiast rolnictwo ekologiczne, sprzyjające zachowaniu bioróżnorodności, które jednocześnie nie zanieczyszcza środowiska naturalnego. Efektem wsparcia rządów państw Unii Europejskiej, a w szczególności wprowadzenia dotacji dla gospodarstw ekologicznych, jest szybki przyrost ich liczby oraz wzrost powierzchni gruntów rolnych użytkowanych zgodnie z zasadami zrównoważonego rolnictwa (Barłowska i in. 2017). W Polsce rolnictwo ekologiczne zaczęło dynamicznie rozwijać się dopiero po 2004 roku, w którym zarejestrowano 3705 ekologicznych producentów rolnych. W kolejnych latach (aż do 2013 roku) odnotowywano systematyczny wzrost liczby producentów. W 2013 roku Polska miała już 26598 ekologicznych gospodarstw rolnych. W późniejszym okresie, tj. w latach 2013-2015, odnotowano spadek liczby producentów. Dopiero rok 2016 znowu przyniósł ożywienie tego typu działalności rolnej - pod koniec tego roku aktywnych było 22435 egr (ryc. 1).

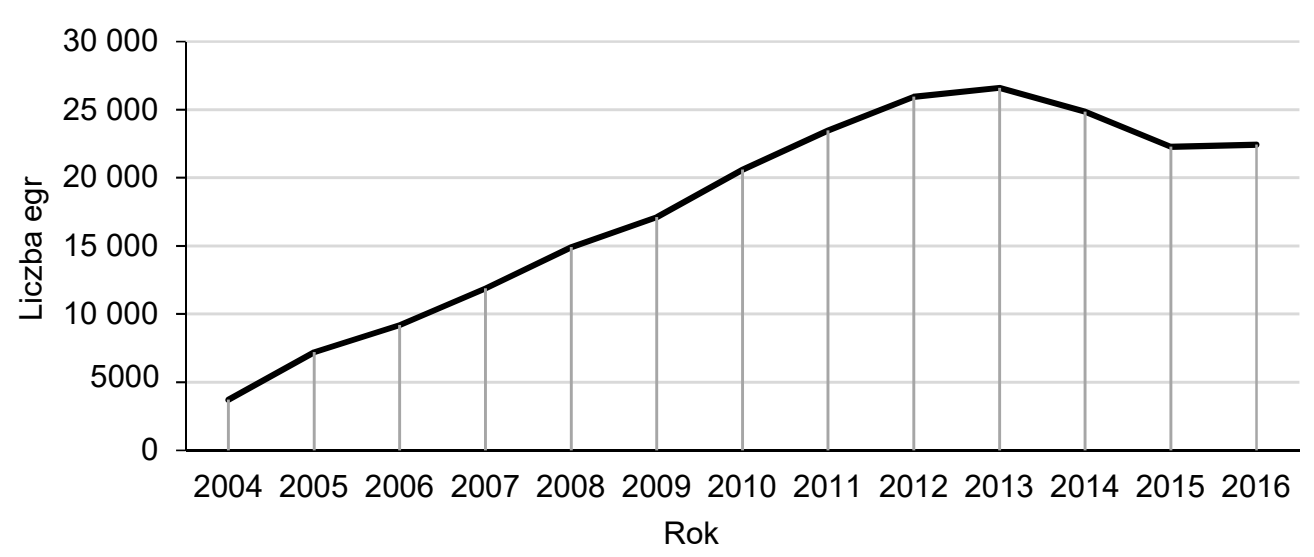

Ryc. 1. Ekologiczne gospodarstwa rolne (egr) w Polsce w latach 2004-2016

Źródło: Raport o stanie rolnictwa ekologicznego w Polsce w latach 2015-2016 (2017). 
Mimo wzrostu liczby producentów „eko”, powierzchnia ekologicznych użytków rolnych obecnie jest najmniejsza od 6 lat. W 2016 r. wyniosła prawie 536,6 tys. ha, w 2015 r. - 580,7 tys. ha. Najwięcej powierzchni uprawy ekologiczne w Polsce zajmowały w 2013 roku - prawie 670 tys. ha. W 2015 r. powierzchnia użytków rolnych, na których prowadzona była produkcja ekologiczna, stanowiła około 4,0\% wszystkich użytków rolnych w Polsce, a w 2016 r. udział ten wynosił już tylko 3,7\% (Rolnictwo ekologiczne w Polsce... 2017).

Spośród wszystkich producentów ekologicznych zarejestrowanych w 2016 roku najwięcej prowadziło działalność w województwach: warmińsko-mazurskim (4054 producentów, którzy stanowili 17,6\% łącznej liczby producentów ekologicznych w Polsce), podlaskim (3296 producentów, którzy stanowili 14,3\% łącznej liczby producentów ekologicznych w Polsce) oraz zachodniopomorskim (3072 producentów, którzy stanowili 13,3\% łącznej liczby producentów ekologicznych w Polsce). Województwa te przodowały również pod względem liczby gospodarstw rolnych: 4041 - w woj. warmińsko-mazurskim, 3273 - w woj. podlaskim, 3043 w woj. zachodniopomorskim. Liczba ekologicznych gospodarstw rolnych w tych województwach (10 357) stanowiła niemal połowę (46,5\%) wszystkich gospodarstw ekologicznych w Polsce. Między innymi powyższe dane i dane zaprezentowane w tab. 1 były podstawą do tego, by badania dotyczące wpływu egr na rozwój lokalny przeprowadzić właśnie w tych województwach. W pierwszej fazie badań (które są podstawą niniejszej pracy) wybrano województwo zachodniopomorskie. W tabeli 2 przedstawiono, jak rozwijało się rolnictwo ekologiczne w województwie zachodniopomorskim w latach 2004-2016.

Tabela 2. Rolnictwo ekologiczne w województwie zachodniopomorskim w latach 2004-2016

\begin{tabular}{|l|r|r|r|r|r|r|r|r|r|r|r|}
\hline \multicolumn{1}{|c|}{ Cechy } & \multicolumn{9}{|c|}{ Lata } \\
\cline { 2 - 14 } & 2004 & 2005 & 2006 & 2007 & 2008 & 2009 & 2010 & 2011 & 2012 & 2015 & 2016 \\
\hline $\begin{array}{l}\text { Liczba producen- } \\
\text { tów ekologicznych }\end{array}$ & 182 & 411 & 690 & 1071 & 1410 & 1713 & 2392 & 3090 & 3600 & 3072 & 2773 \\
\hline Liczba egr & 176 & 404 & 689 & 1071 & 1410 & 1713 & 2388 & 3065 & 3579 & 3043 & 2679 \\
\hline Miejsce w Polsce & 9 & 8 & 6 & 5 & 5 & 4 & 1 & 1 & 2 & 3 & 3 \\
\hline $\begin{array}{l}\text { Powierzchnia egr } \\
\text { [tys. ha] }\end{array}$ & 155 & 270 & 304 & 590 & 561 & 684 & 959 & 1195 & 1352 & 1149 & 1006 \\
\hline $\begin{array}{l}\text { Powierzchnia egr } \\
\text { w woj. zachodnio- } \\
\text { pomorskim w sto- } \\
\text { sunku do powierz- } \\
\text { chni egr w Polsce } \\
\text { [\%] }\end{array}$ & 14,8 & 16,2 & 13,3 & 20,6 & 17,8 & 20,3 & 18,9 & 19,8 & 20,4 & 19,8 & 18,7 \\
\hline Liczba przetwórców & 6 & 7 & 12 & 13 & 12 & 27 & 23 & 16 & 24 & 25 & 26 \\
\hline
\end{tabular}

Źródło: Rolnictwo ekologiczne w województwie zachodniopomorskim (http://eregion.wzp.pl), Rolnictwo ekologiczne w Polsce... (http://www.pomorska.pl/strefa-agro/wiadomosci/a/rolnictwo-ekologiczne-w-polsce-w-raporcie-2017-ilumamy-producentow,12546748), Raport o stanie rolnictwa... (2017).

Ważnym podkreślenia jest również fakt, iż tylko w województwie zachodniopomorskim struktura powierzchni egr (ryc. 2) jest na tyle korzystna (z dużą przewagą gospodarstw dużych i bardzo dużych), że pozwala przyjąć założenie, że skala oddziaływania egr na lokalną społeczność i gospodarkę powinna być w miarę silna i zauważalna. 


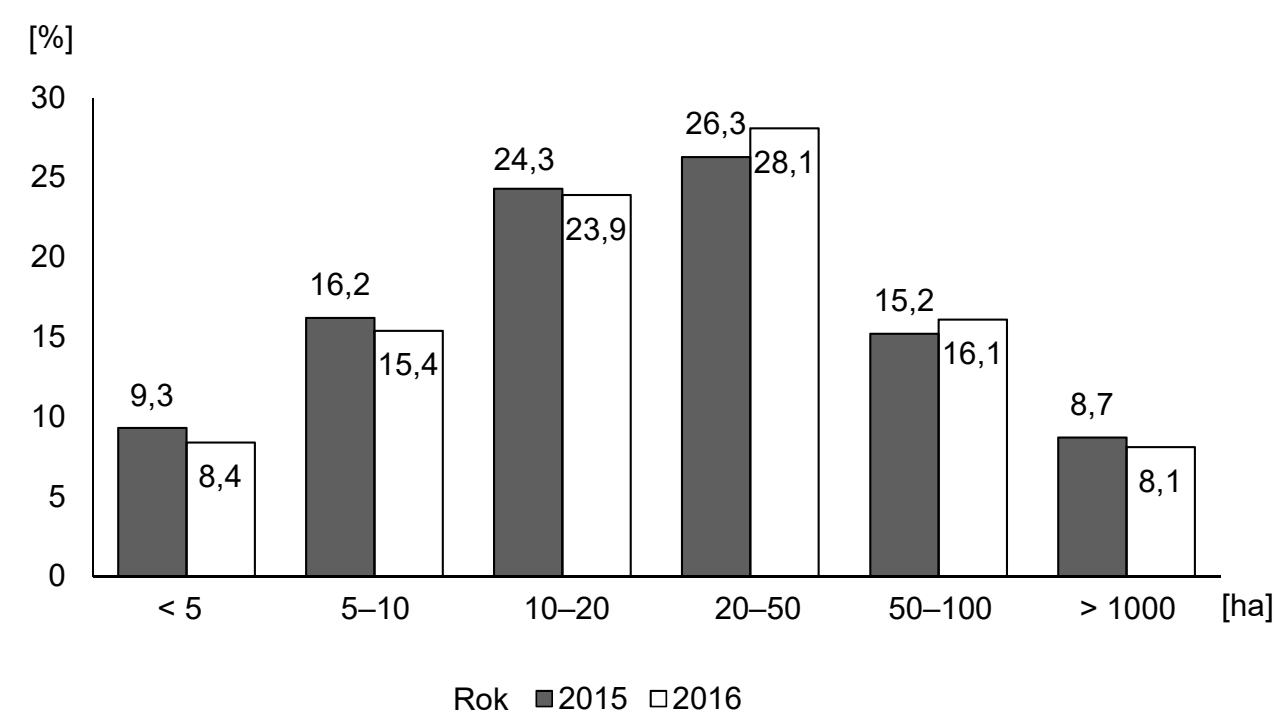

Ryc. 2. Struktura wielkości gospodarstw ekologicznych w woj. zachodniopomorskim w latach 2015 i 2016 [\%]

Źródło: Raport o stanie rolnictwa... (2017).

W 2015 roku gospodarstwa małe (do 10) ha zajmowały 25,5\% powierzchni wszystkich egr w woj. zachodniopomorskim; rok później stanowiły już tylko $23,8 \%$. Z kolei gospodarstwa od 10 do 50 ha w 2016 roku stanowią trzon egr na omawianym terenie i zajmują ponad $52 \%$ powierzchni wszystkich egr (w 2015 roku - 50,6\%). Największe gospodarstwa (powyżej 50 ha) zajmowały w 2015 roku 23,9\%, a w 2016 - 24,2\% całej powierzchni poddanej uprawom „eko”.

\section{WYNIKI}

$\mathrm{Na}$ forum europejskim prowadzone są dyskusje nad rzeczywistymi funkcjami rolnictwa we współczesnej gospodarce. Uznano, że dobrym rozwiązaniem (przedsięwzięciem) dla krajów europejskich - w obliczu zmian gospodarczych (m.in. wobec postępującego rozwoju globalizacji) - będzie poszukiwanie nowych funkcji dla rolnictwa, które pozwolą odróżnić to rolnictwo od rolnictwa w pozostałych rejonach świata. Toteż oprócz tradycyjnych funkcji, tj. funkcji produkcyjnej i funkcji usługowej, coraz częściej w Unii Europejskiej zwiększa się udział funkcji przestrzenno-środowiskowej. Pogląd ten bazuje na założeniu, że system ekonomiczny jest tylko częścią ekosystemu, natomiast egr - jak żadne inne gospodarstwa doskonale wpisuje się w zakres komponentów, jakie zostały wyznaczone w europejskim modelu rolnictwa. Gospodarstwo funkcjonujące zgodnie z wymogami rolnictwa ekologicznego stoi przed trudnym wyzwaniem godzenia praw i zasad ekonomii z poszanowaniem praw przyrody, oczekiwań społeczeństwa z oczekiwaniami producentów, dążenia do zaspokojenia potrzeb współczesnych z interesami przyszłych pokoleń (Kondratowicz-Pozorska 2013).

$\mathrm{Na}$ ryc. 3 przedstawiono rozkład odpowiedzi (na 15 pytań zadanych w ankiecie) mieszkańców wsi, w których funkcjonują egr. Wszyscy respondenci w 100\% odpowiedzieli twierdząco tylko na pierwsze pytanie. Potwierdzili tym samym, że dostrzegają to, iż produkcja w egr, nie niszcząc środowiska naturalnego, dostarcza produkty zdrowe i wysokiej jakości. Najmniejszą wiedzę mieszkańcy mieli nt. roli egr w depopulacji i dezertyfikacji terenów wiejskich oraz zagospodarowania odpadów i recyklingu. Także pytanie 10 dotyczące przeciwdziałania klęskom żywiołowym nie wiązało się ankietowanym z działaniami egr. 


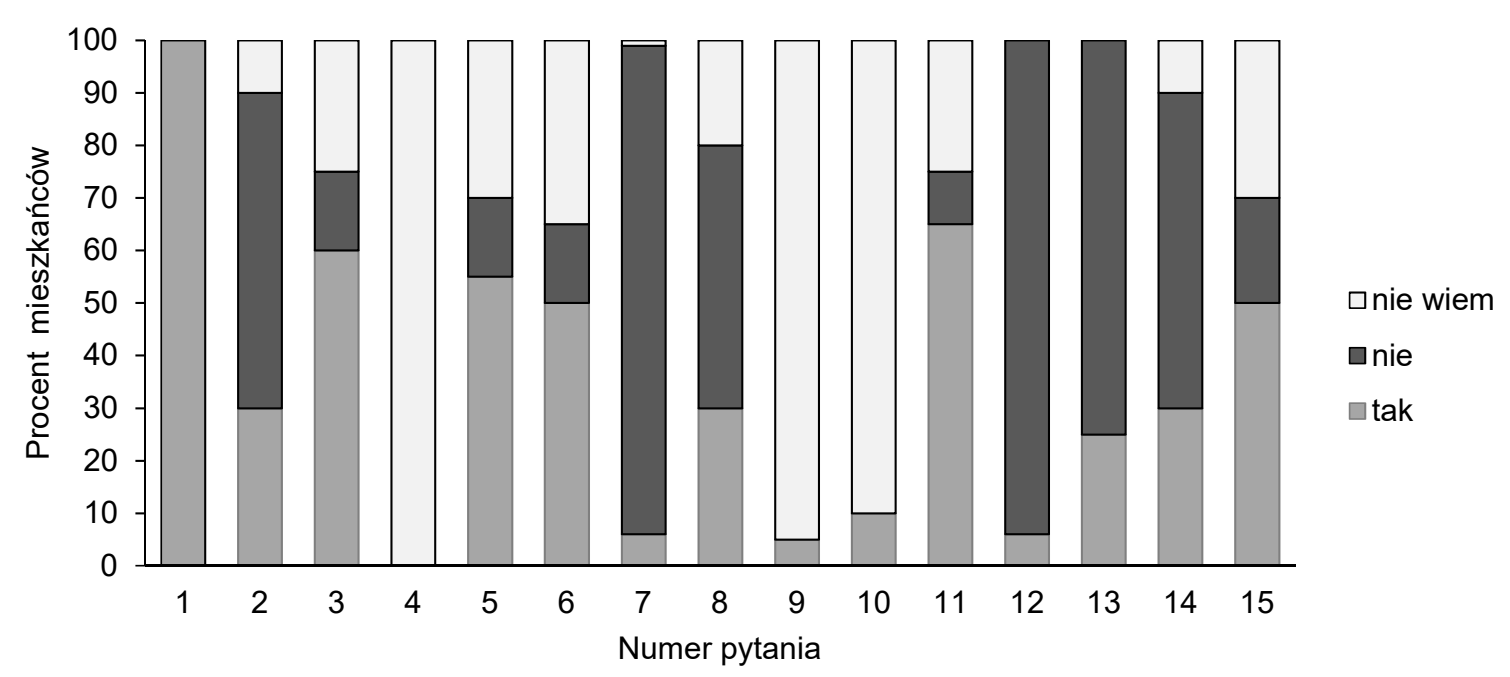

Ryc. 3. Struktura odpowiedzi uzyskanych od mieszkańców wsi

Tylko na pytania 3, 5, 11 i 15 połowa lub ponad połowa ankietowanych mieszkańców wsi udzieliła odpowiedzi twierdzącej. Natomiast trudne do wytłumaczenia jest to, dlaczego tak duży procent odpowiedzi negatywnych dotyczy pytań 2, 7 i 8 . Warto w przyszłości zastanowić się, dlaczego sąsiedzi egr nie potrafili dostrzec tego, czy egr sprzedają wyprodukowane przez siebie płody, czy przygotowują grunt pod rozwój pozarolniczych funkcji obszarów wiejskich oraz rozwój turystyki i infrastruktury z nią związanej. Mieszkańcy wsi nie potwierdzają, że egr tworzą miejsca pracy (95\% odpowiedzi negatywnych), jednocześnie aż $75 \%$ badanych nigdy nie było na terenie egr funkcjonującego w okolicy. Dobrym sygnałem jest natomiast to, że $60 \%$ respondentów uważa, iż działania egr nie wpływają negatywnie na komfort ich życia, a wręcz odwrotnie: dostrzegają aktywność egr w inicjowaniu społeczno-kulturalnych działań (50\% odpowiedzi pozytywnych) na terenie ich gminy.

Zupełnie inaczej działania i funkcję egr oceniają wójtowie gmin (ryc. 4).

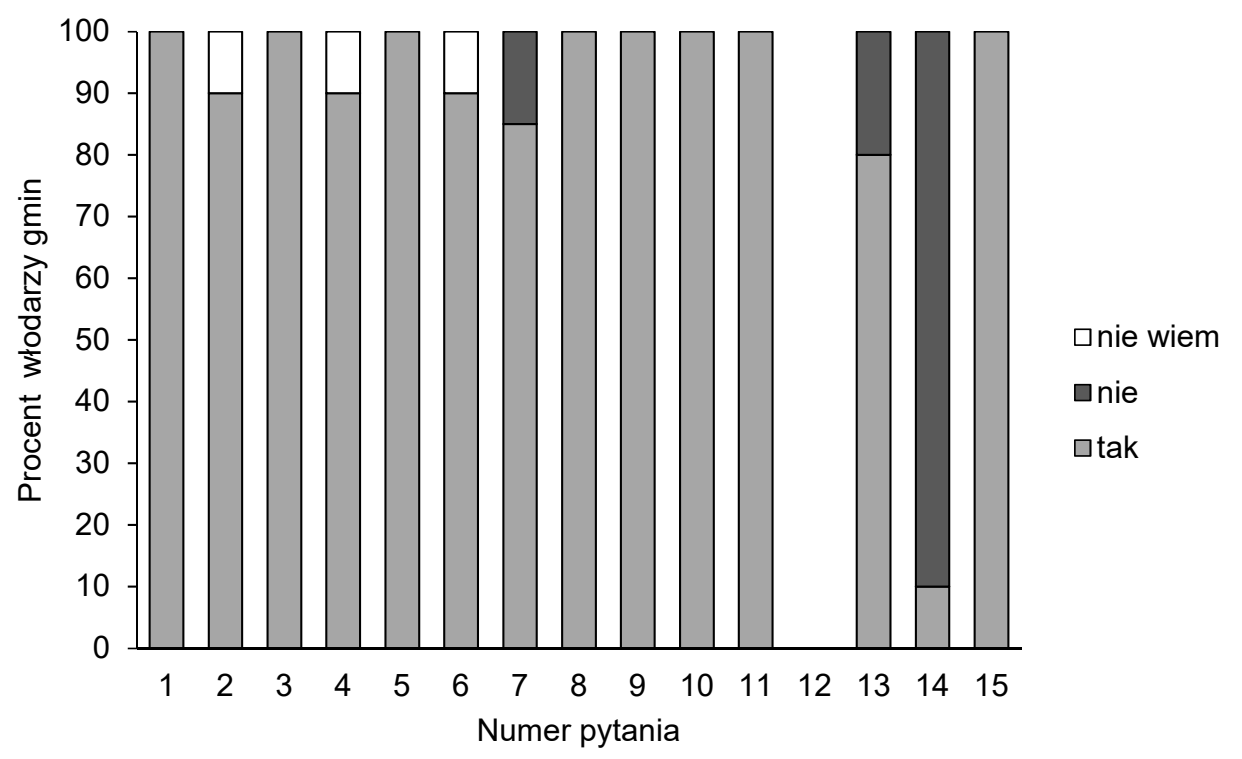

Ryc. 4. Struktura odpowiedzi uzyskanych od włodarzy gmin 
W tej grupie badanych dominowały odpowiedzi twierdzące. Tylko na pytania 2, 4 i 6 w około $10 \%$ odpowiedzi wskazano „nie wiem”. Ponadto na pytania 7, 13 i 14 obok odpowiedzi twierdzących pojawiły się także odpowiedzi przeczące. Interesujący jest fakt, że $15 \%$ wójtów wskazało, że egr nie przyczyniają się do rozwoju pozarolniczych funkcji obszarów wiejskich, mimo że aż $80 \%$ osób zarządzających gminą było z wizytą w takich gospodarstwach. Ostatecznie jednak aż 90\% badanych zaznaczyło, że egr na terenie ich gmin nie utrudniają rozwoju lokalnego innych podmiotów. Jednak, jak wskazano w ankietach, zatrudnienie w egr znajduje niewielu mieszkańców wsi. Liczby wpisane do ankiety przy pytaniu 12 dotyczyły osób zatrudnionych w egr - zawierają się one w przedziale od 3 do 17 , z czego ok. $70 \%$ wskazań dotyczy pracowników sezonowych.

Analizując strukturę odpowiedzi na pytania zawarte w ankiecie, dochodzi się do wniosku, że stan wiedzy przedsiębiorców o roli egr i o możliwości współpracy z nimi na rzecz lokalnego rozwoju jest stosunkowo niewielki (ryc. 5).

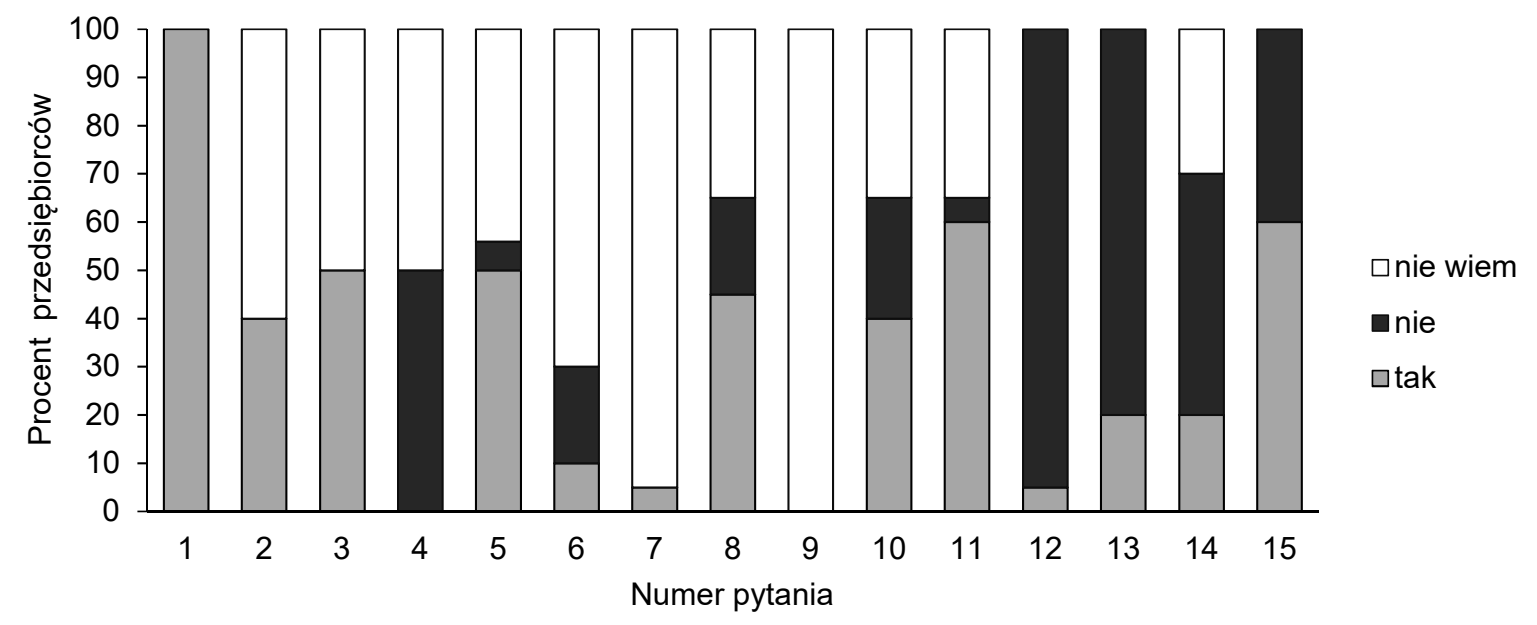

Ryc. 5. Struktura odpowiedzi uzyskanych od lokalnych przedsiębiorców

Tylko na pytania $1,3,5,11$ i 15 połowa lub więcej niż połowa badanych udzieliła odpowiedzi twierdzącej. Tym samym potwierdziła, że egr wytwarzają produkty ekologiczne zgodnie z zasadami ekologii, dbają o krajobraz, propagują walory lokalnej przyrody i jednocześnie troszczą się o środowisko. Spełniają również funkcje edukacyjno-dydaktyczne poprzez dbanie o dziedzictwo kulturowe i historyczne wsi. Odpowiedzi „nie” zdecydowanie przeważały w przypadku pytań 4, 12, 13 i 14. Najmniejszą wiedzę przedsiębiorcy mieli nt. roli egr w depopulacji i dezertyfikacji terenów wiejskich, bowiem na odpowiedzi „nie” lub „nie wiem" przypadało po $50 \%$ odpowiedzi. Zdecydowanie negatywne jest także to, że pomimo iż co piąty przedsiębiorca był na terenie egr, tylko $5 \%$ badanych $w$ tej grupie łączy współpraca z egr. Brakuje zatem odpowiednich instytucji, doradców, którzy powiążą te dwie grupy producentów i wskażą im możliwości współdziałania z korzyścią dla lokalnej społeczności i całego regionu.

Wśród odpowiedzi udzielonych na pytanie nr 15 dominowały odpowiedzi wskazujące, że przedstawiciele egr byli inicjatorami lub uczestnikami uroczystości gminnych, jarmarków, wystaw, spotkań dydaktycznych w szkołach itp. Poza tym w czterech gminach wskazano, że to egr były inicjatorami tworzenia stowarzyszeń działających w ramach LGD. 
W przypadku pytań 1-11 respondenci, którzy udzielili odpowiedzi twierdzącej, mogli jednocześnie ocenić skalę działań prowadzonych przez egr na terenie ich wsi. Na ryc. 6 przedstawiono średnie ocen wyliczone dla poszczególnych działań egr wskazanych w 11 pierwszych pytaniach ankiety. Na zewnętrznej części diagramu umieszczono numery pytań. Na wewnętrznej osi umieszczono oceny, gdzie 1 oznacza ocenę bardzo złą, 2 - niedostateczną, 3 - dostateczną, 4 - dobrą, 5 - bardzo dobrą, 6 - wyróżniającą. Każdy $z$ respondentów, który pozytywnie odpowiedział na pytania od 1 do 11 , mógł więc określić, z jaką siłą egr realizują dane działanie, przyczyniając się do rozwoju lokalnego.

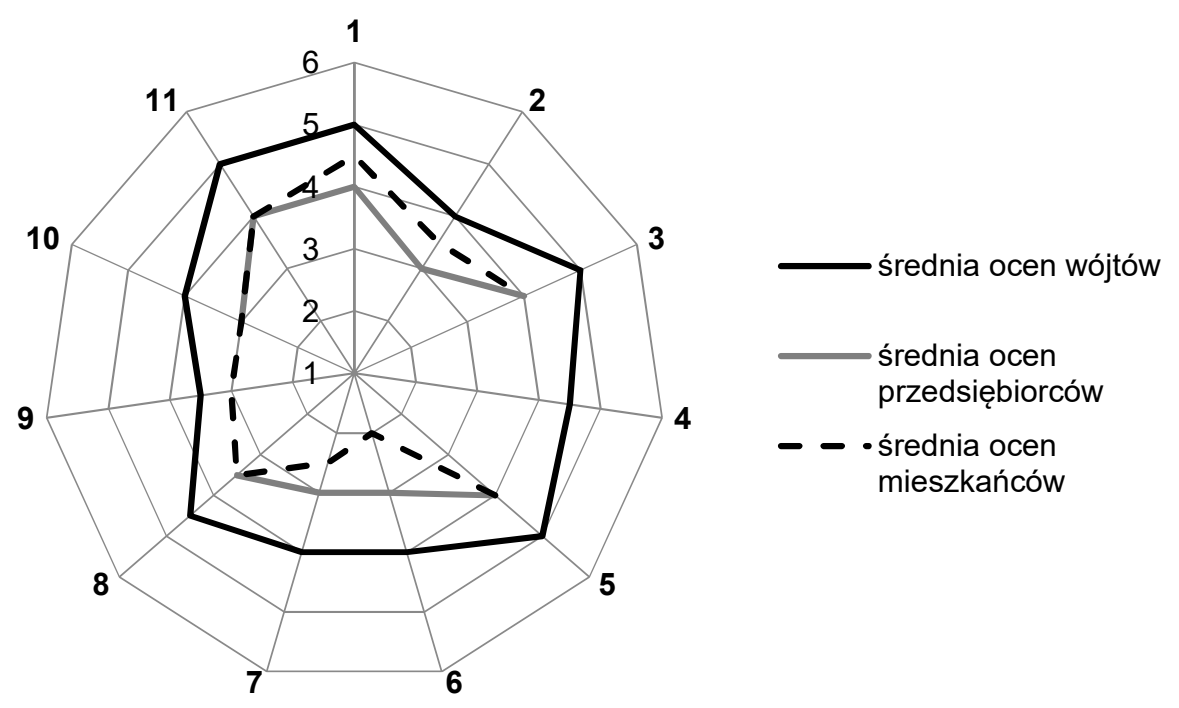

Ryc. 6. Rozkład średniej ocen uzyskanych na pierwszych 11 pytań, przy zaznaczeniu przez ankietowanych odpowiedzi „tak”

Jak przedstawiono na ryc. 6 , nikt nie ocenił pracy egr, wystawiając ocenę wyróżniającą. Najwyższe noty egr wystawili wójtowie. Ocenę bardzo dobrą uzyskały działania produkcyjne, przestrzenne i kształtowania krajobrazu oraz dotyczące zachowania walorów tradycji i historii wsi. Najniżej włodarze ocenili natomiast starania o zachowanie czystości i zbiórkę odpadów odnawialnych (średnia ocena wyniosła 3,5). Pozostałym czynnościom wystawiono ocenę dobrą lub dobrą plus.

Z kolei mieszkańcy wsi oraz przedsiębiorcy będący sąsiadami egr zdecydowanie bardziej krytycznie ocenili funkcjonowanie gospodarstw ekologicznych i ich wpływ na rozwój lokalny. Średnie ocen oscylują od oceny niedostatecznej do co najwyżej dobrej plus. Ocenę niedostateczną mieszkańcy wsi wystawili egr za kreowanie miejsc pracy, najwyższą - dobrą plus za realizację funkcji produkcyjnej. Przedsiębiorcy natomiast najniżej ocenili (tylko na ocenę dostateczną) starania egr w zakresie sprzedaży produktów ekologicznych, kreowania miejsc pracy, tworzenia pozarolniczych funkcji obszarów wiejskich oraz zapobiegania klęskom i katastrofom. Dobre noty u przedsiębiorców zyskały działania egr związane z produkcją, w tym dotyczące wykorzystania przestrzeni na potrzeby gospodarcze i społeczne, udostępniania zainteresowanym lokalnych zasobów przyrody oraz starania o zachowanie dziedzictwa. 


\section{WNIOSKI}

1. Lokalne społeczeństwo z pewnością docenia rolę egr jako producentów zdrowej, wysokiej jakości żywności.

2. Egr postrzegane są ponadto jako podmioty, które produkując, nie niszczą środowiska naturalnego, a wręcz odwrotnie: chronią je, konserwują i właściwie kształtują krajobraz wsi.

3. Charakter pracy egr łączy się z działaniami zmierzającymi do zachowania lokalnej tradycji, kultury, poznania historii miejsca. Każda z badanych grup zauważyła również takie działania egr, jak organizowanie lokalnych uroczystości, imprez kulturalnych, spotkań dydaktycznych itp.

4. Funkcjonowanie egr w większości przypadków nie przeszkadza ani lokalnej ludności, ani przedsiębiorcom w realizacji codziennych czynności. Także wójtowie nie są przeciwni, by w gminie rozwijały się podmioty gospodarcze o innym profilu działalności.

5. Z badań wynika, że egr realizują sprzedaż produktów ekologicznych z dala od miejsca produkcji, co powoduje, że okoliczni mieszkańcy nie czerpią korzyści z tego, że sąsiadują z egr.

6. Egr funkcjonują głównie dzięki wytężonej pracy właściciela i członków jego rodziny. Dlatego lokalna społeczność nie uważa, że ich istnienie przyczynia się do powstawania nowych miejsc pracy i przeciwdziała depopulacji.

7. Mieszkańcy i przedsiębiorcy nie zauważyli szczególnego zaangażowania egr w proces zagospodarowywania odpadów i recyklingu, a władze gmin oceniły tę działania dość nisko, wystawiając ocenę dostateczną plus.

8. Egr powinny zdecydowanie wzmocnić swoją lokalną pozycję i wizerunek, bowiem najbliższe środowisko, w którym funkcjonują, właściwie ich nie zna. Efektem tego jest niska średnia ocen zadań realizowanych przez egr, która waha się od 2 do 4,5 (bez ocen wystawionych przez wójtów).

9. Właściciele egr powinni również wzmocnić działania zmierzające do nawiązania silniejszych więzi z okolicznymi przedsiębiorcami, zakładami pracy, placówkami oświatowo-dydaktycznymi. Wszystko to sprawi, że zostaną ożywione inwestycje ipozarolnicze funkcje obszarów wiejskich, a także zrewitalizowane lub stworzone przestrzenie rekreacyjne na obszarach wiejskich.

Reasumując, można stwierdzić, że wkład egr w rozwój lokalny zachodniopomorskiej wsi jest zdecydowanie za niski w stosunku do ich możliwości.

\section{PIŚMIENNICTWO}

Adamowicz M. 2005. Zrównoważony i wielofunkcyjny rozwój rolnictwa a agronomia. Lublin, UMCS, 79.

Barłowska J., Wolanciuk A., Idec J. 2017. Rolnictwo ekologiczne w Polsce na tle Unii Europejskiej i świata. Prz. Hod. 2, 1-5, http://ph.ptz.icm.edu.pl/wp-content/uploads/2017/03/1-Barłowska-.pdf, dostęp: 5.05.2018.

Bezpieczeństwo żywnościowe dzięki zrównoważonemu wzrostowi - gospodarka rolna oparta na ograniczonych zasobach, http://www.farmer.pl/fakty/unia-europejska/produkcja-zywnosci-topodstawowy-cel-rolnictwa,33957.html, dostęp 5.05.2018.

Domagalska J., Buczkowska M. 2015. Rolnictwo ekologiczne - szanse i perspektywy rozwoju. Probl. Hig. Epidemiol. 96(2), 370-376. 
Komorowska D. 2015. Znaczenie rolnictwa ekologicznego w Polsce. Rocz. Nauk. SERiA 17(2), 119-126.

Kondratowicz-Pozorska J. 2013. Ekonomiczno-organizacyjne determinanty konkurencyjności ekologicznych gospodarstw rolnych w Polsce. Szczecin, PTE, 225-288.

Raport o stanie rolnictwa ekologicznego w Polsce w latach 2015-2016. 2017. Warszawa, IJHARS, 24, 101-102.

Rolnictwo ekologiczne w Polsce w raporcie 2017. Ilu mamy producentów? Gazeta Pomorska, http://www.pomorska.pl/strefa-agro/wiadomosci/a/rolnictwo-ekologiczne-w-polsce-w-raporcie-2017-ilu-mamy-producentow, 12546748, dostęp: 5.05.2018.

Rolnictwo ekologiczne w województwie zachodniopomorskim. Portal eRegion Zachodniopomorskie, http://eregion.wzp.pl, dostęp: 5.05.2018.

Sobiecki R. 2007. Globalizacja a funkcje polskiego rolnictwa. Warszawa, SGH, 276-277.

Szarek S., Nowogródzka T. 2015. Regionalne zróżnicowanie rozwoju rolnictwa ekologicznego w Polsce. J. Agr. Rural Dev. 1(35), 125-135.

Streszczenie. Celem pracy jest ocena korzyści z rozwoju rolnictwa ekologicznego w województwie zachodniopomorskim i jego wpływu na lokalną gospodarkę, społeczeństwo i środowisko. Na podstawie danych z ankiet próbowano ocenić, czy gospodarstwa ekologiczne są uważane przez okoliczną ludność i władze danego regionu za pożądane oraz w jaki sposób ich istnienie przyczynia się do jego rozwoju. Postrzegane są jako podmioty, które produkując, nie niszczą środowiska naturalnego, a wręcz odwrotnie: chronią je, konserwują i właściwie kształtują krajobraz wsi. Powinny zdecydowanie wzmocnić swoją lokalną pozycję, bowiem najbliższe środowisko, w którym funkcjonują, właściwie ich nie zna. Wkład gospodarstw ekologicznych w rozwój lokalny zachodniopomorskiej wsi jest zdecydowanie za mały w stosunku do jej możliwości. 
